University of Nebraska - Lincoln

DigitalCommons@University of Nebraska - Lincoln

Publications, Agencies and Staff of the U.S.

Department of Commerce

U.S. Department of Commerce

2012

\title{
Comparison of methods for the detection of coliphages in recreational water at two California, United States beaches
}

\author{
Roberto A. Rodríguez \\ University of North Carolina at Chapel Hill, ralerodriguez12@gmail.com \\ David C. Love \\ University of North Carolina at Chapel Hill \\ Jill R. Stewart \\ University of North Carolina at Chapel Hill, jill.stewart@unc.edu \\ Julianne Tajuba \\ University of North Carolina at Chapel Hill \\ Jacqueline Knee \\ University of North Carolina at Chapel Hill \\ See next page for additional authors
}

Follow this and additional works at: https://digitalcommons.unl.edu/usdeptcommercepub

Part of the Environmental Sciences Commons

Rodríguez, Roberto A.; Love, David C.; Stewart, Jill R.; Tajuba, Julianne; Knee, Jacqueline; Dickerson, Jerold W. Jr.; Webster, Laura F.; and Sobsey, Mark D., "Comparison of methods for the detection of coliphages in recreational water at two California, United States beaches" (2012). Publications, Agencies and Staff of the U.S. Department of Commerce. 354.

https://digitalcommons.unl.edu/usdeptcommercepub/354

This Article is brought to you for free and open access by the U.S. Department of Commerce at DigitalCommons@University of Nebraska - Lincoln. It has been accepted for inclusion in Publications, Agencies and Staff of the U.S. Department of Commerce by an authorized administrator of DigitalCommons@University of Nebraska - Lincoln. 


\section{Authors}

Roberto A. Rodríguez, David C. Love, Jill R. Stewart, Julianne Tajuba, Jacqueline Knee, Jerold W.

Dickerson Jr., Laura F. Webster, and Mark D. Sobsey 


\title{
Comparison of methods for the detection of coliphages in recreational water at two California, United States beaches
}

\author{
Roberto A. Rodríguez $^{\mathrm{a}, *}$, David C. Love ${ }^{\mathrm{a}}$, Jill R. Stewart ${ }^{\mathrm{a}, \mathrm{b}}$, Julianne Tajuba ${ }^{\mathrm{a}}$, Jacqueline Knee ${ }^{\mathrm{a}}$, \\ Jerold W. Dickerson Jr ${ }^{\mathrm{b}}$, Laura F. Webster ${ }^{\mathrm{b}}$, Mark D. Sobsey ${ }^{\mathrm{a}}$ \\ a Department of Environmental Sciences and Engineering, Gillings School of Global Public Health, University of North Carolina at Chapel Hill, Chapel Hill, NC 27514, USA \\ b NOAA National Ocean Service, Charleston, SC 29412, USA
}

\section{Article history:}

Received 5 October 2009

Received in revised form 10 January 2012

Accepted 16 January 2012

Available online 25 January 2012

\section{Keywords:}

Somatic coliphages

Male-specific coliphages

Two-step enrichment

Single agar layer

Rapid CLAT coliphage detection

Seawater

Latex agglutination immunoassay

\begin{abstract}
A B S T R A C T
Methods for detection of two fecal indicator viruses, $\mathrm{F}+$ and somatic coliphages, were evaluated for application to recreational marine water. Marine water samples were collected during the summer of 2007 in Southern California, United States from transects along Avalon Beach ( $n=186$ samples) and Doheny Beach $(n=101$ samples). Coliphage detection methods included EPA method 1601 - two-step enrichment (ENR), EPA method 1602 - single agar layer (SAL), and variations of ENR. Variations included comparison of two incubation times (overnight and 5-h incubation) and two final detection steps (lysis zone assay and a rapid latex agglutination assay). A greater number of samples were positive for somatic and $\mathrm{F}+\mathrm{col}-$ iphages by ENR than by SAL $(p<0.01)$. The standard ENR with overnight incubation and detection by lysis zone assay was the most sensitive method for the detection of $\mathrm{F}+$ and somatic coliphages from marine water, although the method takes up to three days to obtain results. A rapid 5-h enrichment version of ENR also performed well, with more positive samples than SAL, and could be performed in roughly $24 \mathrm{~h}$. Latex agglutination-based detection methods require the least amount of time to perform, although the sensitivity was less than lysis zone-based detection methods. Rapid culture-based enrichment of coliphages in marine water may be possible by further optimizing culture-based methods for saline water conditions to generate higher viral titers than currently available, as well as increasing the sensitivity of latex agglutination detection methods.
\end{abstract}

(c) 2012 Elsevier B.V. All rights reserved.

\section{Introduction}

Water bodies near population centers often become contaminated with fecal material originating from storm water runoff and sewage. Municipal sewage is treated and disinfected in the United States (USA) to reduce loading rates of nutrients and human pathogens in surface waters, although malfunctioning on-site septic systems, broken or leaking sewer pipes and combined-sewer overflows can result in the release of untreated sewage and its pathogens into water bodies (Griffin et al., 2003). Monitoring waters for the presence of all human pathogens is done, but not commonly, because of the high cost and the technical requirements. Instead, fecal indicator bacteria (FIB) such as Enterococcus spp., coliforms, and Escherichia coli are used for monitoring the quality of fresh and marine recreational waters. Thresholds for determining the safety of recreational water were established for FIB using epidemiological data obtained from beaches with a point

\footnotetext{
* Corresponding author at: Department of Civil, Environmental and Agricultural Engineering, University of Colorado, UCB 428, Boulder, CO, USA.

E-mail address: ralerodriguez12@gmail.com (R.A. Rodríguez).
}

source of sewage contamination, such as sewage outfalls (reviewed in Pruss, 1998; Wade et al., 2003). The efficacy of FIB and fecal indicator viruses (e.g. coliphages and Bacteriodes fragilis phages) to prevent exposure to human pathogens may depend on the beach setting, sources of fecal contamination, and ecology of the indicator organism. For example, at beaches with point sources of sewage contamination, FIB correlate better with the incidence of disease in bathers than coliphages (Wade et al., 2010). At beaches with unknown sources or nonpoint sources of fecal contamination, the presence of coliphages has correlated with onset of diseases more often than the presence of FIB (Colford et al., 2007; Abdelzahel et al., 2011). These findings indicate that there may be some water bodies where coliphages may be appropriate as indicators of bathing water quality.

Coliphages are viruses that infect $E$. coli and other coliform bacteria. Two functional types of coliphages exist in the environment: male-specific $(\mathrm{F}+)$ and somatic coliphages. $\mathrm{F}+$ coliphages infect their bacterial hosts by attachment to the F-pilus of the cell. Therefore, $\mathrm{F}+$ coliphages only infect hosts that contain the $\mathrm{F}+$ plasmid and can produce F-pili. Somatic coliphages infect bacterial hosts by direct attachment to cell walls. Coliphages have been suggested as indicators for the presence of enteric viruses in water because they 
are similar physiologically to some human enteric viruses, and are often found in the intestinal tract of humans and animals (Havelaar, 1987; Havelaar et al., 1993; Skraber et al., 2004). Coliphages are persistent in the environment and have been found in waste, surface and ground waters and in sand (Kott et al., 1978; Havelaar et al., 1993; Bonilla et al., 2007). Some studies have found a correlation between the presence of coliphages and human viruses (Ballester et al., 2005; Havelaar et al., 1993; Jiang et al., 2001), while others have found no correlation between them (Ibarluzea et al., 2007; Jiang et al., 2007).

Several standardized methods are available in the US and EU for the detection of coliphages in water (USEPA, 2001a,b; European Committee for Standardization, 1995). In 2001, the United States Environmental Protection Agency (EPA) approved two methods for monitoring coliphages in ground water: the two-step enrichment EPA method 1601 (ENR) and the single agar layer EPA method 1602 (SAL). These methods have been applied to estuarine, river, and surface water (Stewart-Pullaro et al., 2006; Bonilla et al., 2007; Ballester et al., 2005; Love et al., 2010a,b). SAL is a plaque assay method used to enumerate coliphages in volumes up to $100 \mathrm{~mL}$ (USEPA, 2001a) and ENR is a liquid culture enrichment test developed originally for presence/absence analysis but has been modified by quantification of multiple volumes as a most probable number (MPN) test for total volumes up to $1 \mathrm{~L}$ (USEPA, 2001b; Sobsey et al., 2004). A recent method combines ENR and latex agglutination serotyping to monitor fecal contamination rapidly (Love and Sobsey, 2007) and has been validated for the detection of fecal contamination from beach waters (Griffith et al., 2009).

The goal of this study was to compare methods for the detection of $\mathrm{F}+$ and somatic coliphages in marine waters used for primary contact recreation. Methods evaluated included ENR, SAL, and variations of ENR using two incubation times (overnight incubation versus 5-h incubation) and two final detection steps (lysis zone assay versus latex agglutination). Two beaches located in California, US were included in the study, each with different types of fecal contamination sources. This study will determine effective methods for detection of coliphages in marine water.

\section{Materials and methods}

\subsection{Methods development for the detection of $\mathrm{F}+$ coliphages}

Unpublished observations demonstrated that the growth of the E. coli host $\mathrm{F}_{\mathrm{amp}}$ is affected negatively by high salinities commonly found in marine water samples (data not shown). Because poor growth of $E$. coli host is related to poor method performance, we addressed this issue by increasing the amount (and hence concentration) of the bacterial host for analyzing seawater sample from $5 \mathrm{~mL}$ to $50 \mathrm{~mL}$ of log-phage $E$. coli host. An experiment was conducted to compare method performance in different water matrices over time. In this experiment, seawater or sterile deionized water (DI water) were spiked with $0.3-0.6 \mathrm{PFU} / 100 \mathrm{~mL}$ of three $\mathrm{F}+$ coliphages in separate experiments and each experiment were performed in triplicate into, processed by ENR, and tested after 3, 5,7 , and 16 h of enrichment (Table 2 ).

\subsection{Sample collection}

Water samples were collected from Doheny State Beach (Doheny Beach) in Dana Point, CA and Avalon Beach in the town of Avalon, Catalina Island, CA. Doheny Beach and Avalon Beach each have a history of beach closures due to high concentration of FIB. At Doheny Beach, the primary source of water quality impairment is non-point source fecal contamination (Dorsey, 2010). Four sampling stations were located linearly along Doheny Beach where marine water samples were collected. In Doheny Beach, another sampling station was located across a sand berm from the Pacific Ocean, in a lagoon at the terminus of San Juan Creek where creek water samples were collected. At Avalon Beach, a sewage line leaks raw sewage into tidal groundwater that flows to the beach (Boehm et al., 2003, 2009). Three sampling stations were located across Avalon Beach.

At all stations and beaches, water samples were collected on Saturday and Sunday, and during holidays of Fourth of July and Labor Day during the summer of 2007. Water samples were collected at $0.5 \mathrm{~m}$ depth (i.e. ankle to knee depth) as specified by the California County Health Departments. Samples were collected three times a day at $7 \mathrm{am}, 1 \mathrm{pm}$, and $3 \mathrm{pm}$ for Doheny Beach and $8 \mathrm{am}, 12 \mathrm{pm}$ and $3 \mathrm{pm}$ for Avalon Beach. In total, 103 water samples were collected at Doheny Beach and 186 samples were collected at Avalon Beach. Water samples were chilled at $4{ }^{\circ} \mathrm{C}$ and then shipped overnight on frozen ice packs by commercial air carrier to the laboratory where they were analyzed. The maximum holding time for these samples was $72 \mathrm{~h}$.

\subsection{Coliphage detection}

Sample volumes, quantification units, and the time needed to obtain results with each method are provided in Table 1. E. coli $\mathrm{F}_{\mathrm{amp}}$ (ATCC 700891) was used as the host for detection of F+ coliphages and E. coli CN13 (ATCC 700609) was used for somatic coliphage detection. As prescribed in standard coliphage analysis methods (USEPA, 2001a,b), culture media for detection of $\mathrm{F}+$ coliphages were supplemented with streptomycin (final concentration $15 \mu \mathrm{g} / \mathrm{mL}$ ) and ampicillin (final concentration $15 \mu \mathrm{g} / \mathrm{mL}$ ), and culture media for somatic coliphages was supplemented with nalidixic acid (final concentration $100 \mu \mathrm{g} / \mathrm{mL}$ ).

EPA method 1601 (ENR) was used for most probable number (MPN) estimation of coliphage concentrations as described previously by Sobsey et al. (2004) with the exception that a log-phase host volume of $50 \mathrm{~mL}$ was added for $\mathrm{F}+$ coliphage enrichments instead of $5 \mathrm{~mL}$. One-liter sample volume enrichments were aliquoted (after mixing and before incubation) in sub-sample volumes of $300 \mathrm{~mL}, 30 \mathrm{~mL}$ and $3 \mathrm{~mL}$ in triplicate for $\mathrm{F}+$ coliphage detection, and in subsample volumes of $30 \mathrm{~mL}, 3 \mathrm{~mL}$ and $0.3 \mathrm{~mL}$ in triplicate ( $100 \mathrm{~mL}$ total volume) for somatic coliphage detection. The sample volume was lower for somatic coliphages because preliminary results showed that their concentrations were higher than those of F+ coliphages at these beaches (data not shown). Enrichment sub-samples of $1 \mathrm{~mL}$ were taken after $5 \mathrm{~h}$ and after overnight incubation, to determine if shorter incubation periods give results equivalent to overnight incubation. Sub-samples were centrifuged at $10,000 \times g$ for $10 \mathrm{~min}$ to remove bacterial cells and $10 \mu \mathrm{L}$ was pipetted ('spot-plated') onto tryptic soy agar (TSA) plates containing host bacteria and antibiotics. After a 16-h incubation step, spots were scored for lysis zones and the combination of positives was used to compute MPN estimates.

In addition to the spot-plate detection method, the rapid antibody-based, coliphage latex agglutination and typing (CLAT) method (Love and Sobsey, 2007) was performed to detect F+ coliphage in water samples after $5 \mathrm{~h}$ of incubation ( $5 \mathrm{~h}$-ENR-CLAT) and after overnight incubation (Ov-ENR-CLAT). Samples were scored as positive based on formation of clumps visible on the agglutination card after $60 \mathrm{~s}$. Absence of such clumps signified negative samples.

EPA method 1602 (SAL) was performed following standard protocols using $100 \mathrm{~mL}$ sample volumes for $\mathrm{F}+$ and somatic coliphages (USEPA, 2001b).

\subsection{Statistical analysis}

Coliphage methods were compared using the Wilcoxon SignedRank Test and Chi-Square using nominal (positive/negative) data. 
Table 1

Methods for coliphage detection in marine water.

\begin{tabular}{|c|c|c|c|c|}
\hline Method & Coliphages & Sample volumes & Quantification unit & Time until results \\
\hline EPA 1602 single agar layer (SAL) & $\begin{array}{l}\mathrm{F}+\text { coliphage, somatic } \\
\text { coliphage }\end{array}$ & $100 \mathrm{~mL}$ & Plaque forming units & $\begin{array}{l}16-24 \mathrm{~h} \text { culture and } \\
\text { detection }\end{array}$ \\
\hline \multirow[t]{2}{*}{ EPA 1601 two-step enrichment (ENR) } & $\mathrm{F}+$ coliphage & $\begin{array}{l}\text { Total vol. }=1 \text { L sub-samples: } \\
300 \mathrm{~mL} \times 3 \\
30 \mathrm{~mL} \times 3 \\
3 \mathrm{~mL} \times 3\end{array}$ & $\begin{array}{l}\text { MPN, }{ }^{a} \text { positive volumes as zones of } \\
\text { lysis }\end{array}$ & $\begin{array}{l}16-24 \mathrm{~h} 1 \mathrm{st} \\
\text { culture } \pm 12-16 \mathrm{~h} 2 \mathrm{nd} \\
\text { culture } 28-40 \mathrm{~h} \text { total }\end{array}$ \\
\hline & Somatic coliphages & $\begin{array}{l}\text { Total vol. }=100 \mathrm{~mL} \text { sub-samples: } \\
30 \mathrm{~mL} \times 3 \\
3 \mathrm{~mL} \times 3 \\
0.3 \mathrm{~mL} \times 3\end{array}$ & $\begin{array}{l}\text { MPN, positive volumes as zones of } \\
\text { lysis }\end{array}$ & $\begin{array}{l}16-24 \mathrm{~h} 1 \mathrm{st} \\
\text { culture } \pm 12-16 \mathrm{~h} 2 \mathrm{nd} \\
\text { culture } 28-40 \mathrm{~h} \text { total }\end{array}$ \\
\hline $5 \mathrm{~h}$ enrichment (5-h-ENR) & $\mathrm{F}+$ coliphages & $\begin{array}{l}\text { Total vol. }=1 \mathrm{~L} \text { sub-samples: } \\
300 \mathrm{~mL} \times 3 \\
30 \mathrm{~mL} \times 3 \\
3 \mathrm{~mL} \times 3\end{array}$ & $\begin{array}{l}\text { MPN, positive volumes as zones of } \\
\text { lysis }\end{array}$ & $\begin{array}{l}5 \mathrm{~h} \text { initial culture } \\
\text { period }+12-16 \mathrm{~h} 2 \mathrm{nd} \\
\text { culture period for } \\
\text { overnight enrichment } \\
17-21 \mathrm{~h} \text { total }\end{array}$ \\
\hline $5 \mathrm{~h}$ enrichment-CLAT (5-h-ENR-CLAT) & $\mathrm{F}+$ coliphages & $\begin{array}{l}\text { Total vol. }=1 \mathrm{~L} \text { sub-samples: } \\
300 \mathrm{~mL} \times 3 \\
30 \mathrm{~mL} \times 3 \\
3 \mathrm{~mL} \times 3\end{array}$ & $\begin{array}{l}\text { MPN; positive volumes as particle } \\
\text { Immuno-agglutination }\end{array}$ & $\begin{array}{l}5 \mathrm{~h} \text { culture } \pm 1 \mathrm{~min} \\
\text { detection } 5 \mathrm{~h} \text { total }\end{array}$ \\
\hline Overnight enrichment (ENR-CLAT) & $\mathrm{F}+$ coliphages & $\begin{array}{l}\text { Total vol. }=1 \mathrm{~L} \text { sub-samples: } \\
300 \mathrm{~mL} \times 3 \\
30 \mathrm{~mL} \times 3 \\
3 \mathrm{~mL} \times 3\end{array}$ & $\begin{array}{l}\text { MPN; positive volumes as particle } \\
\text { immuno-agglutination }\end{array}$ & $\begin{array}{l}16-20 \text { h culture } \pm 1 \mathrm{~min} \\
\text { detection } 16-20 \mathrm{~h} \text { total }\end{array}$ \\
\hline
\end{tabular}

a $\mathrm{MPN}=$ most probable number.

In this study, the performance of new methods was benchmarked to the standard EPA method 1602 (ENR), because in other waters ENR has been the most sensitive method (Love et al., 2010a,b). The equation for sensitivity was: sensitivity = true positive/(true positive + false negative). A 'true positive' was defined as a sample positive by ENR and by the new methods tested. A 'false negative' was defined as a sample positive by ENR but negative by the new methods tested.

\section{Results}

\subsection{Methods development for the detection of F+ coliphages}

Preliminary experiments were performed to determine the effect of salinity and incubation time for detection of low concentrations of $\mathrm{F}+$ coliphages. During the first three time points $(3,5$, and $7 \mathrm{~h}$ ) more DI water samples were positive for $\mathrm{F}+$ coliphage than seawater samples (Table 2). After $16 \mathrm{~h}$ of enrichment both water matrices were equivalent in the number of $\mathrm{F}+$ coliphage positive samples. These results demonstrate that the two-step enrichment method using overnight incubation $(16 \mathrm{~h}$ ) performs similarly when detecting coliphages at very low concentration in seawater samples or deionized water samples.

Table 2

Effect of salinity and incubation time during enrichment for the detection of low concentration of $\mathrm{F}+$ coliphages.

\begin{tabular}{cll}
\hline Enrichment duration $(\mathrm{h})$ & $\begin{array}{l}\mathrm{F}+\text { coliphage detection frequency } \\
\text { (positive/total) }\end{array}$ \\
\cline { 2 - 3 } & In deionized water & In seawater $^{\mathrm{b}}$ \\
\hline 3 & $5 / 9$ & $0 / 9$ \\
5 & $7 / 9$ & $2 / 9$ \\
7 & $9 / 9$ & $6 / 9$ \\
16 & $9 / 9$ & $9 / 9$ \\
\hline
\end{tabular}

${ }^{a} \mathrm{~F}+$ coliphage concentrations prior to enrichment were between 0.3 and $0.6 \mathrm{PFU} / 100 \mathrm{~mL}$. The $\mathrm{F}+$ coliphages used were $\mathrm{Q} \beta$, Sp and Fd, each in triplicate.

b In seawater samples, a higher concentration of $E$. coli $\mathrm{F}$-amp host was used than in deionized water samples.

\subsection{Comparison of five methods for the detection of $\mathrm{F}+$ coliphage} at two beaches

In the summer of 2007, 289 water samples, and 103 samples at Doheny Beach and 186 samples at Avalon Beach were tested by five $\mathrm{F}+$ coliphage detection methods. The method with the highest proportion of positive samples was ENR with $27 \%$ positive at Doheny Beach and 61\% positive at Avalon Beach (Fig. 1). Samples were assayed after $5 \mathrm{~h}$ of enrichment (5-h-ENR) and after overnight enrichment (ENR) to determine whether rapid culture was effective. At Doheny Beach, the percentage of positive samples was less for 5-h-ENR (18\%) than ENR $(27 \%)(p<0.05)$, and
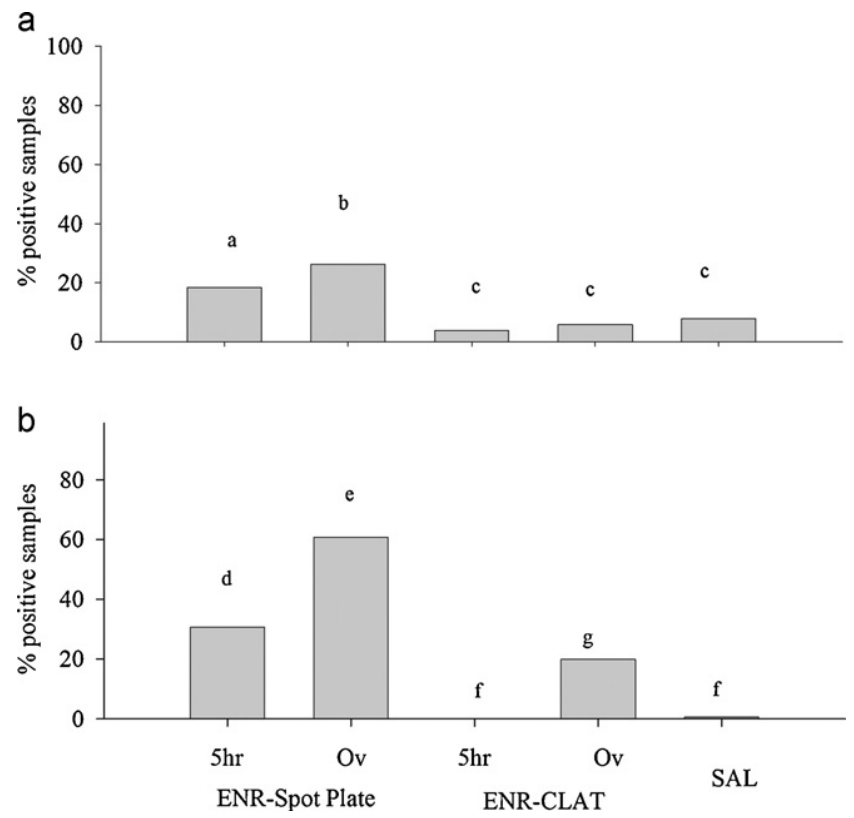

Fig. 1. Methods comparison for the detection of $F+$ coliphages in seawater at $(A)$ Doheny Beach and (B) Avalon Beach in Summer 2007. Different superscript letters $(\mathrm{a}, \mathrm{b}, \mathrm{c}$, etc.) in each figure represents significant differences $(p<0.01)$ between methods as determined by using the two-sided probabilities obtained from the Wilcoxon signed rank test. Please see Table 1 for the description of each method and its corresponding abbreviation. 


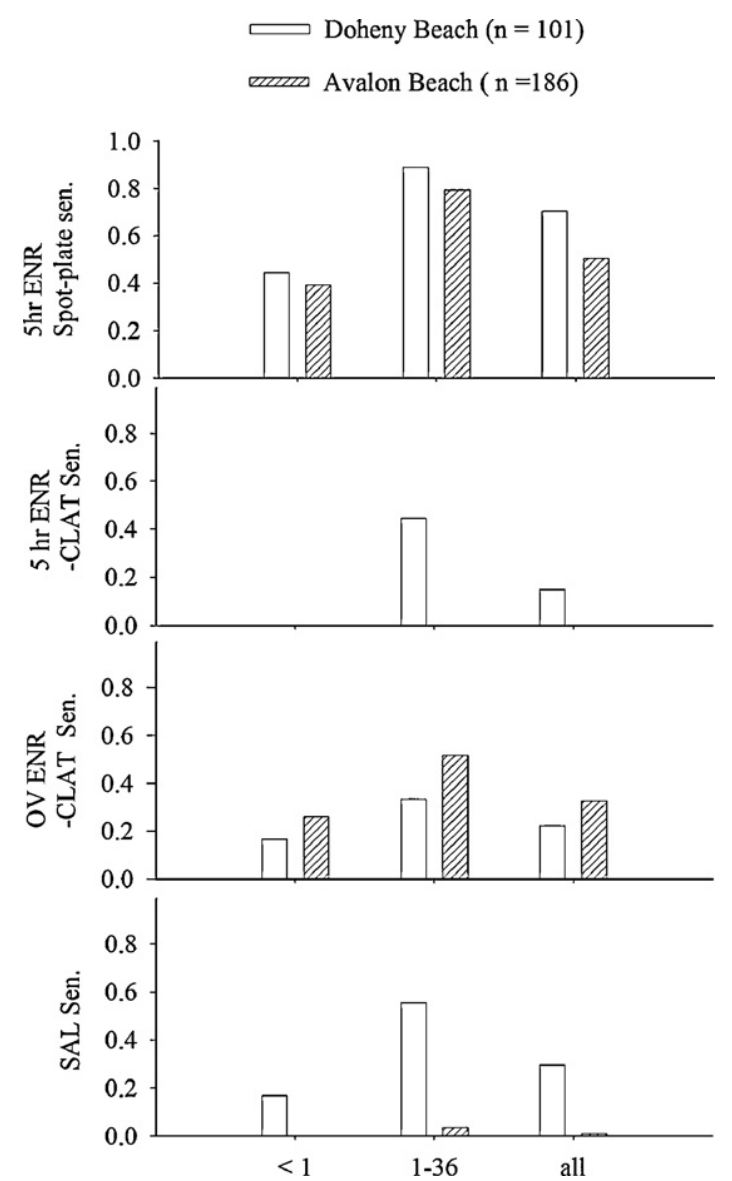

Fig. 2. Sensitivity (Sen.) of rapid and overnight $\mathrm{F}+$ coliphage detection methods when compared to the ENR for sample MPN concentration categories of $<1 \mathrm{MPN} / 100 \mathrm{ml}, 1-36 \mathrm{MPN} / 100 \mathrm{~mL}$, and all samples (overall). Where no bars are present, samples were all negative by that method. Please see Table 1 for the description of each method and its corresponding abbreviation.

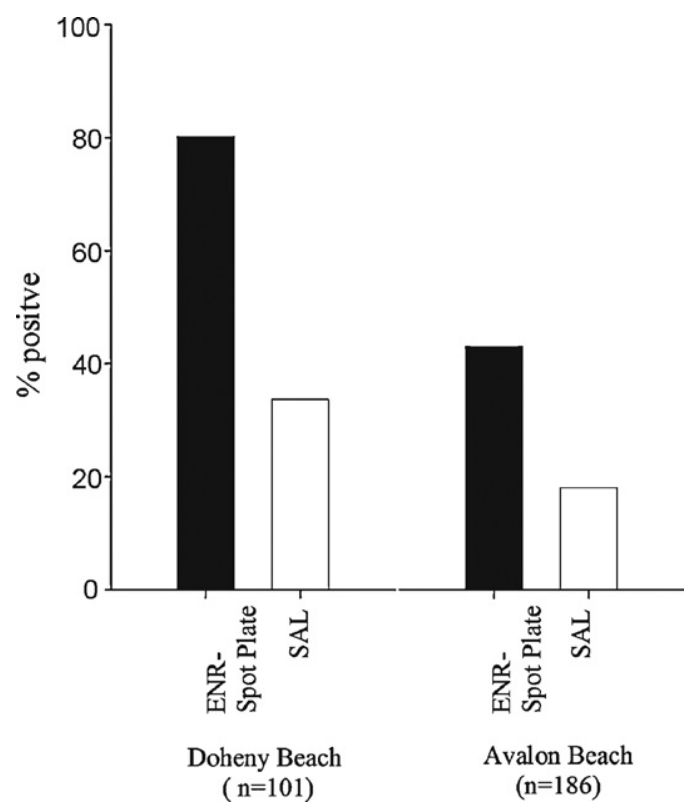

Fig. 3. Comparison of the two step enrichment (ENR) and single agar layer (SAL) for somatic coliphage detection at two beaches. There was a significant difference $(p<0.01)$ between ENR and SAL in percent of positive samples at each beach. In addition, there was a significant difference between beaches $(p<0.01)$ in the percent of positive samples for each method. Please see Table 1 for the description of each method and its corresponding abbreviation.
Table 5

Cross tabulation of the results obtained with the two-step enrichment (ENR) and the single agar layer (SAL) for the detection of somatic coliphages in Doheny Beach, California, USA samples.

\begin{tabular}{|c|c|c|c|c|}
\hline & \multicolumn{3}{|l|}{$S A L^{\mathrm{a}}$} & \multirow[t]{2}{*}{ Chi-sq $p$} \\
\hline & Positive & Negative & Totals & \\
\hline \multicolumn{5}{|l|}{$\mathrm{ENR}^{\mathrm{b}}$} \\
\hline Positive & 34 & 47 & 81 & \\
\hline Negative & 0 & 20 & 20 & \\
\hline Total & 34 & 67 & 101 & $<0.001$ \\
\hline
\end{tabular}

a $\mathrm{SAL}=\mathrm{EPA}$ method 1602, single agar layer assay.

b ENR = EPA method 1601, two-step enrichment assay.

Table 6

Cross tabulation of the results obtained with the two-step enrichment (ENR) and the single agar layer (SAL) for the detection of somatic coliphages in Avalon Beach, California, USA samples.

\begin{tabular}{lllrl}
\hline & \multicolumn{2}{l}{ SAL $^{\mathrm{a}}$} & & Chi-sq $p$ \\
\cline { 2 - 4 } & Negative & Positive & Totals & \\
\hline ENR $^{\text {b }}$ & 74 & 25 & 99 & \\
Positive & 85 & 2 & 87 & \\
Negative & 159 & 27 & 186 & $<0.001$ \\
Total & & & & \\
\hline
\end{tabular}

a EPA method 1602, single agar layer assay.

b EPA method 1601, two-step enrichment assay.

than the detection of somatic coliphages by SAL, at either beach (chi square $p<0.001$ ). For Doheny Beach, none of the samples were negative using ENR and positive using SAL. For Avalon Beach, only two samples out of 186 were positive with SAL and negative with ENR.

\section{Discussion}

Of the five methods studied, two-step enrichment (ENR) with overnight incubation was the most sensitive for detecting both $\mathrm{F}+$ and somatic coliphages in California marine waters. In an effort to reduce sample analysis time (i.e. time to results), ENR was tested after $5 \mathrm{~h}$ of incubation and this modification produced the second most sensitive method to detect $\mathrm{F}+$ coliphages. These results suggest that 'rapid' ( $5 \mathrm{~h}$ incubation) ENR methods are applicable to marine waters and could be useful for management of recreational areas. Utilizing 5-h incubation reduces the overall time needed for detection of coliphages by ENR from $40 \mathrm{~h}$ to as few as $17 \mathrm{~h}$. Further modifications could reduce further the time needed to obtain results.

Differences observed between broth culture enrichment-based methods, such as ENR, and plaque-based methods such as SAL, were influenced perhaps by the volume of water analyzed. For F+ coliphages, all modifications of coliphage ENR methods assayed 1-L volumes of water samples, while SAL assayed only $100 \mathrm{~mL}$ volumes of water samples. Comparison studies between ENR and SAL in freshwater and estuarine water have demonstrated that both methods are reliable for detection of both $\mathrm{F}+$ and somatic coliphages; however, ENR is better able to detect coliphages at low concentrations (Sobsey et al., 2004; Love et al., 2010a,b). In a cross validation study of fecal indicators using different types of water spiked with sewage, SAL performed better than ENR in detecting fecal contamination (Griffith et al., 2009). Both methods performed well in detecting human fecal contamination with rates of correct detection over $50 \%$ and $100 \%$ correct classification of negative samples. However, in cases of very low concentrations of coliphages, as demonstrated in the present study, the capacity to analyze 10-fold larger volumes of water and thereby detecting lower concentrations of phages makes ENR more effective. 
When a $100 \mathrm{~mL}$ seawater sample volume was analyzed for the presence of somatic coliphages using ENR and SAL, the former was more sensitive for somatic coliphage detection. Bonilla et al. (2007) reported that a pre-enrichment of samples before SAL increases the number of positive samples when analyzing sand from ocean beaches for the presence of coliphages. However, it was not clear from their study if the volume of the sample analyzed was larger during the pre-enrichment compared with the volume $(100 \mathrm{~mL})$ of sample normally assayed in SAL, or if pre-enrichment fundamentally changed the detection method from being quantitative to presence-absence only. Nevertheless, their results also demonstrated that enrichment is more sensitive than SAL in detecting low concentrations of coliphages in samples with high salinity. Ballester et al. (2005) reported that more estuarine water samples were positive for coliphages when using ENR than when using SAL for detecting coliphages. However, the same samples were not analyzed with both methods and instead samples were collected at different sampling events. One possible explanation why enrichment methods are better at detecting coliphages at very low concentration is that during enrichment coliphages are more efficiently contacting and infecting bacterial cells in a liquid media. In contrast, plaque methods depend only on cell-to-cell infection of adjacent bacterial cells in agar in order to produce visible plaques.

The combined use of a rapid enrichment with a rapid antibodybased latex agglutination assay (CLAT) has been described for detection and typing $\mathrm{F}+$ coliphages in $180 \mathrm{~min}$ in non-saline waters (Love and Sobsey, 2007). The lack of positive samples obtained with 5-h-ENR-CLAT when concentrations of coliphages were $<1$ MPN/100 mL may suggest that coliphage enrichment did not yield final coliphage concentrations high enough to be detected by CLAT. The minimum concentration of coliphages needed to produce agglutination is between $10^{5}$ and $10^{8} \mathrm{PFU} / \mathrm{mL}$ (Love and Sobsey, 2007). The use of spot-plating for confirming the presence of coliphages has a lower detection limit of $100 \mathrm{PFU} / \mathrm{mL}$. Therefore, the detection of coliphages using a rapid enrichment-CLAT will depend on the ability of the enrichment to enrich adequately the otherwise low concentrations of coliphages usually found in water samples to concentrations high enough to be detected by the CLAT. In the present study, longer enrichment incubations yielded more positive CLAT results, but the percent of positive samples was lower than results obtained with standard enrichment-spot plating method (ENR). Despite the low incidence of positive results obtained with the 5-h-ENR-CLAT, the results obtained with this rapid coliphage detection assay were similar to the results obtained with SAL, a method used commonly for the detection of coliphages in beaches. Latex agglutination assays have been used routinely as an analytical tool by microbiological laboratories. There have been improvements introduced such as the use of different types of beads and more directional binding of the immunoglobulin (Inzana, 1995; Molina-Boívar et al., 1998; Perez-Amodio et al., 2001), which may improve performance of the method used in this study. The development of CLAT assay has spurred others to develop a latex agglutination method for Norovirus (Lee et al., 2010).

There are significant benefits to public health by utilizing sensitive methods that yield results in $<24 \mathrm{~h}$ after sampling (as reviewed by Boehm et al., 2009; Girones et al., 2010). Because of the duration of culture-base FIB methods used for monitoring recreational water, there is at least a one-day lag in beach closings and openings. The implication is that beach users could be exposed unnecessarily to water contaminated with fecal material, or that beaches could be closed unnecessarily when the water quality is safe. For this reason, there is a great interest in developing rapid methods, such as real-time PCR, for monitoring water quality (Wade et al., 2010; Griffith et al., 2009). Real-time PCR requires specialized expertise, laboratory facilities and equipment (Girones et al., 2010). At this point, real-time PCR is utilized by nationally recognized and specialized laboratories for monitoring FIB in beach water, although it is unknown how this approach will work for routine sampling and analysis by local laboratories. On the other hand, culture-based coliphage methods do not require improved laboratory facilities. Any laboratory that performs water quality analysis for FIB will be able to perform these methods. However, before applying CLAT to water monitoring programs it will be necessary to improve the CLAT method sensitivity. Rapid methods for monitoring beach water quality, using practicable methods and timely reporting, are needed to minimize bather exposure after fecal contamination events.

\section{Conclusion}

The two-step overnight enrichment (ENR) and spot plating for lysis zones was the most sensitive method for the detection of coliphages from seawater compared to other modifications of the enrichment method and SAL. However, the time required for the detection of coliphages with this method is approximately $36 \mathrm{~h}$. A modified 5-h enrichment-spot plating procedure (5 h-ENR) produced results $24 \mathrm{~h}$ after sampling and its sensitivity in detecting $\mathrm{F}+$ coliphages was better than the single agar layer method (SAL) that yields results in $16 \mathrm{~h}$. The rapid coliphage detection method based on CLAT assay was less sensitive than spot plate lysis zone assay when detecting coliphages at low concentrations but could be useful as part of a tiered strategy to protect bather health.

\section{Acknowledgments}

This work was funded in part by the NOAA Oceans and Human Health Initiative, the Southern California Coastal Water Research Project and the Cooperative Institute of Coastal and Estuarine Environmental Technology.

\section{References}

Abdelzahel, A.M. Wright, M.E. Ortega C. Hasan, A.R. Shibata, T, Solo-Gabriele, H.M., Kish, J., Elmir, S.M., Bonilla, A., Bonilla, T.D., Palmer, C.J., Scott, T.M., Lukasik, J. Harwood, V.J., McQuaig, S., Sinigalliano, C.D., Gidley, M.L., Wanless, D., Plano, L.R. Garza, A.C., Zhu, X., Stewart, J.R., Dickerson, J.W., Yampara-Iquise, H., Carson, C. Fleisher, J.M., Fleming, L.E., 2011. Daily measures of microbes and human health at a non-point source marine beach. J. Water Health 9, 443-457.

Ballester, N.A., Fontaine, J.H., Margolin, A.B., 2005. Occurrence and correlations between coliphages and anthropogenic viruses in the Massachusetts Bay using enrichment and ICC nPCR. J. Water Health 3, 59-68.

Boehm, A.B., Fuhrman, J.A., Mrse, R.D., Grant, S.B., 2003. Tiered approach for identification of a human fecal pollution source at a recreational beach: case study at Avalon Bay, Catalina Island, California. Environ. Sci. Technol. 37, 673-680.

Boehm, A., Yamahara, K., Love, D.C., Peterson, B., McNeill, K., Nelson, K., 2009. Covariation and photoinactivation of traditional and novel indicator organisms and human viruses at a sewage-impacted marine. Environ. Sci. Technol. 43 (21) 8046-8052.

Bonilla, T.D., Nowosielski, K., Cuvelier, M., Hartz, A., Green, M., Esiobu, N., McCorquodale, D.S., Fleisher, J.M., Rogerson, A., 2007. Prevalence and distribution of fecal indicator organisms in South Florida beach sand and preliminary assessment of health effects associated with beach sand exposure. Mar. Pollut. Bull. 54, $1472-2148$.

Colford Jr., J.M., Wade, T.J., Schiff, K.C., Wright, C.C., Griffith, J.F., Sandhu, S.K., Burns, S., Sobsey, M., Lovelace, G., Weisberg, S.B., 2007. Water quality indicators and the risk of illness at beaches with nonpoint sources of fecal contamination. Epidemiology 18, 27-35.

Dorsey, J.H., 2010. Improving water quality through California's clean beach initiative: an assessment of 17 projects. Environ. Monit. Assess. 166, 95-111.

European Committee for Standardization, 1995. European Standard EN ISO 10705 1. Water Quality-Detection and Enumeration of Bacteriophages-Part 1: Enumeration of F-specific RNA Bacteriophages. European Committee for Standardization, Brussels, Belgium.

Girones, R., Ferrús, M.A., Alonso, J.L., Rodriguez-Manzano, J., Calgua, B., Corrêa Ade, A., Hundesa, A., Carratala, A., Bofill-Mas, S., 2010. Molecular detection of pathogens in water-the pros and cons of molecular techniques. Water Res. 44, 4325L 4339.

Griffin, D.W., Donaldson, K.A., Paul, J.H., Rose, J.B., 2003. Pathogenic human viruses in coastal waters. Clin. Microbiol. Res. 16, 129-143.

Griffith, J.F., Cao, Y., McGee, C.D., Weisberg, S.B., 2009. Evaluation of rapid methods and novel indicators for assessing microbiological beach water quality. Water Res. 43, 4900-4907. 
Havelaar, A.H., 1987. Bacteriophages as model organism in water treatment. Microbiol. Sci. 4, 362-364.

Havelaar, A.H., van Olphen, M., Drost, Y.C., 1993. F-Specific RNA bacteriophages are adequate model organisms for enteric viruses in fresh water. Appl. Environ. Microbiol. 59, 2956-2962.

Ibarluzea, J.M., Moreno, B., Serrano, E., Larboru, K., Maiztegi, M.J., Yarzabal, A., Santa Marina, L., 2007. Somatic coliphages and bacterial indicators of bathing water quality in the beaches of Gipuzka, Spain. J. Water Health 5, 417-426.

Inzana, T.J., 1995. Simplified procedure for preparation of sensitized latex particles to detect capsular polysaccharides: application to typing and diagnosis of Actinobacillus pleuropneumoniae. J. Clin. Microbiol. 33, 2297-2303.

Jiang, S.C., Noble, R., Chu, W., 2001. Human adenovirus and coliphages in urban runoff-impacted coastal waters of Southern California. Appl. Environ. Microbiol. 67, 179-184.

Jiang, S.C., Chu, W., He, J.W., 2007. Seasonal detection of human viruses and coliphage in Newport Bay, California. Appl. Environ. Microbiol. 73, 6468-6474.

Kott, Y., Ben-Ari, H., Vinokur, L., 1978. Coliphages survival as viral indicator in various wastewater quality effluents. Progr. Water Technol. 10, 337-346.

Lee, H., Park, Y.-B., Kim, M., Jee, Y., Cheon, D.-S., Jeong, H.S., Ko, G.-P., 2010. Development of a latex agglutination test for norovirus detection. J. Microbiol. 48 (4) 419-425.

Love, D., Silverman, A., Nelson, K., 2010a. Human virus and bacteriophage inactivation by simulated sunlight: a comparison with virus inactivation in marine water at a Southern California beach. Environ. Sci. Technol. 44, 6965-6970.

Love, D., Sobsey, M., 2007. Simple and rapid F+ coliphage culture, latex agglutination and typing assay to detect and source track fecal contamination. Appl. Environ. Microbiol. 73, 4110-4118.

Love, D.C., Lovelace, G.L., Money, E.S., Sobsey, M.D., 2010b. Microbial fecal indicator concentrations in water and their correlation to environmental parameters in nine geographically diverse estuaries. Water Qual. Exp. Health 2 (2), 85-95.

Molina-Boívar, Galisteo-González, J.A., Hidalgo-Alcarez, F., 1998. Latex immunoassays: comparative studies on covalent and physical immobilization of antibodies I. F(ab') $)_{2}$ fragments. J. Biomarker Polym. End. 9, 1089-1101.
Perez-Amodio, S., Holownia, P., Davey, C.L., Price, C.P., 2001. Effects of the ionic environment, charge, and particle surface chemistry for enhancing a latex homogeneous immunoassay of C-reactive protein. Anal. Chem. 73, 3417-3425.

Pruss, A., 1998. Review of epidemiological studies on health effects from exposure to recreational water. Int. J. Epidemiol. 27, 1-9.

Skraber, S., Gassilloud, B., Gantzer, C., 2004. Comparison of coliforms and coliphages as tools for assessment of viral contamination in river water. Appl. Environ. Microbiol. 70, 3644-3649.

Sobsey, M.D., Yates, M.V., Hsu, F.C., Lovelace, G., Battigelli, D., Margolin, A., Pillai, S.D., Nwachuku, N., 2004. Development and evaluation of methods to detect coliphages in large volumes of water. Water Sci. Technol. 50, 211-217.

Stewart-Pullaro, J.M., Daugomah, J.W., Chestnut, D.E., Graves, D.A., Sobsey, M.D. Scott, G.I., 2006. F+ RNA coliphage typing for microbial source tracking in surface waters. J. Appl. Microbiol. 101, 1015-1026.

USEPA, 2001a. Method 1602: Detection of Male-specific $(\mathrm{F}+)$ and Somatic Coliphage in Water by Single Agar Layer (SAL) Procedure. EPA 821-R-01-029. Office of Water, Engineering and Analysis Division, Washington, DC, April.

USEPA, 2001b. Method 1601: Detection of Male-specific $\left(F^{+}\right)$and Somatic Coliphage in Water by Two-Step Enrichment Procedure. EPA 821-R-01-030 Office of Water, Engineering and Analysis Division, Washington, DC (April).

Wade, T.J., Pai, N., Eisenberg, J.N., Colford, J.M., 2003. Do U.S. Environmental Protection Agency water quality guidelines for recreational waters prevent gastrointestinal illness? A systematic review and meta-analysis. J. Environ. Health Persp. 111, 1102-1109.

Wade, T.M., Sams, E., Brenner, K.P., Hougland, R., Chern, M., Beach, B., Wymer, L., Rankin, C.C., Love, D., Li, Q., Noble, R., Dufour, A.P., 2010. Rapidly measured indicators of recreational water quality and swimming-associated illness at marine beaches: a prospective cohort study. Environ. Health 9, 66, http://www.ehjournal.net/content/9/1/66. 